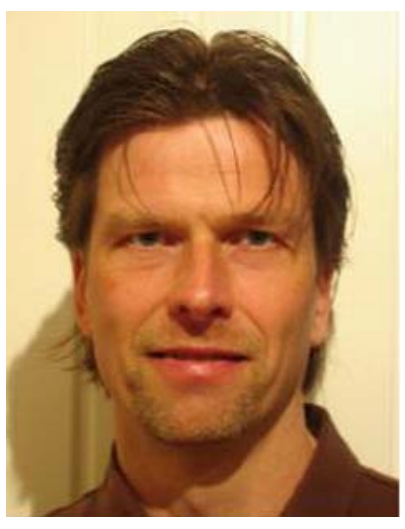

Petri Salo

\section{Mitä on aikuiskasvatus?}

T

iedelehti Aikuiskasvatus synnytettiin neljännesvuosisata sitten aikuiskasvatuksen monimuotoisen kentän yhdyssiteeksi sekä ennakkoluulottomaksi keskustelufoorumiksi. Peruslähtökohdakseen silloinen päätoimittajaryhmä asetti kriittisyyteen ja avoimeen keskusteluun nojaavan aikuiskasvatuksen käytäntöjen tieteenomaisen tarkastelun. Tuolloin elettiin suunnittelun perustuvan kehittämisen yhteiskunnassa ja ajassa. Aikuiskasvatuksen ja -koulutuksen uskottiin edistyvän teorian ja käytännön, tutkimuksen ja kentän sekä vapaan sivistystyön ja ammatillisen aikuiskasvatuksen vuoropuhelua edesauttamalla. Ajatus aikuiskasvattajan (erityisen) ammatti-identiteetin muotoutumisesta perustui1970- ja 1980-luvuilla eri ilmenemismuotoja saaneisiin pyrkimyksiin itsenäisen tieteenalan luomisesta.

Jos tarkastelun kohteeksi otetaan ensinnäkin ulkoiset seikat, on suomalainen aikuiskasvatustiede tänään voimissaan. Meillä on yliopistoissamme alan oppituoleja, virkoja, oma tutkimusseura, säännöllisesti järjestettävät tutkijatapaamiset, tutkimusprojekteja sekä oma tiedelehti. Koska suomalaisen yliopisto- ja akateemisen korkeakoululaitoksen kokonaisbudjetti vastaa vaikkapa yhden suuren amerikkalaisen yliopiston vuosibudjettia, on mielestäni perusteltua jo nyt puhua Suomen yliopistosta. Hajautetulle verkostoperiaatteelle rakentuvana se vastaa informaatioyhteiskunnan keskeisiä lähtökohtia, ajatusmalleja ja toimintatapoja. Koska tieto- ja viestintätekniikka kutistaa välimatkat olemattomiin - tekee ne tietotyössä merkityksettömiksi - ei Suomen yliopiston Aikuiskasvatuksen tiedekuntaa tarvitse koskaan koota saman katon alle, tarkoitusta varten remontoituun tehdaskompleksiin. Lähiopetusta voidaan jatkossakin järjestää usealla eri paikkakunnalla Hangosta Ivaloon. Myös suomalaisen aikuiskasvatustutkimuksen kriittinen massa on hajautettu verkkoon. Aikuiskasvatuksen tiedekunnassa tehtävä tutkimus on tutkimuskohteiltaan ja metodologisilta otteiltaan monipuolista ja laaja-alaista. Kontaktipinta lähitieteisiin ja muihin tieteenaloihin laaja. Omiin havaintoihin perustuva näkemykseni on, että tiedekuntamme on kansainvälisesti tarkasteltuna erittäin vahva.

Mitä annettavaa akateemisella aikuiskasvatustieteellä ja -tutkimuksella tulisi ja voisi olla ns. kentän edustajille ja käytännön aikuiskasvatustyötä tekeville? Pyrin yhä edelleen provosoitumaan kysymyksen kuullessani. Provokatiivinen vastaukseni on: ei mitään. Kysymys perustuu oletukseen tieteen ja käytännön sekä tutkimuksen ja kentän erillisyydestä. Sen lähtökohtana joko-tai -erottelu, ei sekä-että -ajattelu. Dikotomiasta syntyvä hedelmätön kädenvääntö ei vastaa vapaan sivistystyön ja aikuiskasvatuksen pitkän perinteen lähtökohtia, ominaispiirteitä tai työmuotoja. Mieleeni tulee Grundtvigin ajatus hengen ja käden liitosta, Paulo Freiren perustellut näkemykset teorian ja toiminnan orgaanisesta suhteesta, angloamerikkalainen toimintatutkimuksen perinne ja pohjoismainen opintopiiribrändi. 
Mielestäni kysymys halventaa sekä tieteen parissa että kentällä työtään tekeviä. Harva aikuiskasvatustutkija pystynyt välttymään opetustyöltä tai tutkimuksensa esittelyltä seminaareissa ja konferensseissa. En ole koskaan tutkijana kirjoittanut tutkimusraportteja ja artikkeleita itselleni. Tutkimusaineistojen kerääminenkin on aina vuorovaikutukseen perustuva tilanne tai tapahtuma. Kirjoittaminen taas on väline asioiden ja ilmiöiden systemaattisen jäsentelyyn (ts. teoreettisten mallien luomiseen). Tämä koskee yhtä lailla kansanopisto-opettajaa kuin arvostettua aikuiskasvatuksen tutkijaa. Valtaosa suomalaisista aikuiskasvatuksen kentällä päätoimisesti toimivista aikuiskasvattajista, -kouluttajista ja suunnittelijoista on korkeasti koulutettuja inmisja yhteiskuntatieteilijöitä. Näinpä he ovat aikoinaan itsekin paneutuneet tutkimuksen tekemisen "saloihin". Sen paremmin teoriat kuin tutkimusmenetelmälliset valinnat eivät ole heille vieraita.

Olen vuosikausia jo yrittänyt hahmotella (itselleni) vastausta kysymykseen, mitä on aikuiskasvatus? Taustalla on ollut pyrkimys selkeän ja turvallisen (ammatti)identiteetin löytämiseen. Mutta ehkä pyrkimys itsenäisen ja eksklusiivisen tieteenalan määrittelemiseen on syytä vähitellen unohtaa. Hahmotan edustamani aikuiskasvatuksen tietyistä perinteistä ja rakentavasta inmiskuvasta voimansa ammentavaksi inmis- ja yhteiskuntatieteiden kohtauspaikaksi. Edistääksemme aikuiskasvatuksen tutkimusta ja monimuotoisia käytäntöjä sekä niiden välistä vuoropuhelua meidän on kyettävä kohtaamaan toisemme ja keskustelemaan. Keskustelun avaamiseksi ja ylläpitämiseksi tarvitsemme yhteisen ja ymmärrettävän kielen. Lisäksi meidän on kyettävä provosoimaan ja provosoitumaan, ei kuitenkaan kanssatutkijoita tai -ihmisiä ainoastaan kyseenalaistaen, vaan heidän ajatuksiaan kunnioittaen ja ymmärtämään pyrkien.

A

man, Aikuiskasvatuksen, Kansanopiston, LLinEn ja Sivistys.netin päätoimittajat kokoontuivat vuoden alussa pohtimaan suomalaisen "aikuiskasvatusmedian" tilaa ja tulevaisuuden haasteista. Tapaaminen oli käsittääkseni ensimmäinen laatuaan. Toisena huomionarvoinen seikka on aikuiskasvatusmediamme laajuus ja monimuotoisuus. Ainakaan muista pohjoismaista ei vastaavaa aikuiskasvatuksen mediarypästä löydy. Yksi keskeisimmistä ongelmista on omassa kuppikunnassa pitäytyminen, organisatoriset rajat (jota lehdet omalla tavallaan ilmentävät) ylittävän kiinnostuksen ja keskustelun puute. Aikuiskoulutuksen Maailman uusimmassa numerosta, jossa keskustelun ydinkohdat julkaistiin, löytyy myös alan lehtien perustiedot. Aikuiskasvatuksen osalta haluan täydentää lehden toimitusresursseja. Toimitussihteerin ja ns. oto-päätoimittajan lisäksi lehden yksi tärkeimmistä resursseista 4-6 kertaa vuodessa keskustelemaan kokoontuva toimituskunta. Kerran vuodessa kokoontuva toimitusneuvosta puolestaan luotaa lehden linjaa pidemmälle tulevaisuuteen.

\section{PETRI SALO}

psalo@abo.fi 